\title{
Rize Merkez İlçesi Kültürel Peyzaj Alanlarında Zamansal Değişimin Coğrafi Bilgi Sistemleri İle Belirlenmesi
}

\section{Bengi KORGAVUŞ}

Yeditepe Üniversitesi, Mimarlık Fakültesi, Peyzaj Mimarlığı Bölümü, İstanbul.

\author{
Eser Bilgisi: \\ Araştırma makalesi \\ Sorumlu yazar: Bengi KORGAVUŞ, e-mail:bdemirkan@yeditepe.edu.tr \\ doi: http://dx.doi.org/10.17474/acuofd.36327
}

\section{ÖZET}

$\mathrm{Bu}$ çalışmanın amacı bir kültürel peyzaj alanı olarak seçilen Rize Merkez ilçesinin 1955-2009 yılları arasındaki kültürel peyzaj dokusunun; arazi kullanım şekilleri ve arazi örtüsünün zamansal değişiminin Coğrafi Bilgi Sistemleri (CBS) yardımı ile tespit edilmesi ve bu değişimin altında yatan faktörlerin irdelenmesidir. Bu amaçla 1955, 1989 ve 2009 yıllarına ait hava fotoğrafları, topoğrafik haritalar, önceden üretilmiş haritalar, raporlar gibi sayısal ve sayısal olmayan verilerin Coğrafi Bilgi Sistemleri yardımı ile bilgisayar ortamına aktarılması, yorumlama, analiz ve sayısallaştırma işlemleri sonucunda her üç tarih dilimi için arazi örtüsü ve arazi kullanım şekilleri tespit edilmiştir. Daha sonra, 54 yıllık süreç içerisinde, zamansal değişim gösteren arazi örtüsü ve arazi kullanım şekilleri nitelikleri ve nicelikleri ile ortaya konmuştur. $\mathrm{Bu}$ değişimlerin altında yatan faktörlerinin neler olduğunu ve bu değişimi nasıl etkilediklerini anlamak amacı ile yerel yöneticiler, kamu kurum ve kuruluşları ile görüşmeler yapılmıştır. Çalışmanın son aşamasında ise, önceki aşamalarında elde edilen değerlendirme ve analiz sonuçları temel alınarak, Rize Merkez'de zamansal kültürel peyzaj değişiminin ortaya çıkardığı sorunlar ve çözümleri üzerine genel bir değerlendirme yapılmış ve çözüm önerileri sunulmuştur.

Anahtar kelimeler: Kültürel peyzaj, Kültürel peyzaj değişimi, Coğrafi bilgi sistemleri (CBS), Rize

\section{Article Info:}

Research article

Corresponding author: Bengi KORGAVUŞ, e-mail:bdemirkan@yeditepe.edu.tr

\section{Determination of Cultural Landscape Area Changes Using Geographic Information System (GIS) in Rize Merkez District}

\section{ABSTRACT}

This study covers the selected region of cultural landscape area, Rize Merkez district, between the years of 1955-2009 and scrutinizes Rize Merkez district's cultural landscape structure; land use and land cover and its change in time with the use of the Geographic Information System (GIS) and analysis of the causes leading to this transformation. For this purpose, aerial photographs dated on 1955, 1989 and 2009 , digital and non-digital data, topographic maps, thematic maps, pre-generated maps and reports are analyzed, digitized, interpreted, mapping by using the Geographic Information System for all these three time slots. In addition, this analysis, in the course of 54 years, has revealed the change both qualitatively and quantitatively, in land use and land cover of terrain over time. In order to identify the factors with their role on affecting this change, interviews were conducted with local administrators, government bodies and organizations. The last section of this research, based on the interpretation and analytical results from the previous sections, problems that stem from the change in cultural landscape in Rize Merkez district are identified and solution recommendations to these problems are offered.

Keywords: Cultural landscape, Cultural landscape change, Geographic information system (GIS), Rize 


\section{GIRIŞ}

Kültürel peyzaj, içeriğinin çok geniş olmasindan dolayı, sinırlandirmakta güçlük çekilen bir kavram olmasına rağmen birçok tanımı yapılmıştır. $\mathrm{Bu}$ tanımlardan bazıları şunlardır;

Amerikalı coğrafyacı Sauer'ın "sosyal bir topluluğun kültürel yaşantısı ile şekillendirdiği doğal bir coğrafi alan" ve "Kültür etken, doğa araç, kültürel peyzaj ise sonuçtur" (Head 2001) tanımı, güncel tanımına oldukça yakındır.

UNESCO'nun Dünya Kültürel Mirası Komitesi tarafından hazırlanan rehberde kültürel peyzajlar insanoğlunun içinde yaşadığı doğal çevre ile karş1lıklı ilişkilerinin ortaya çıkardığı çeşitliliği kapsamaktadır ve kültürel peyzajlar "insanoğlu ve onun doğal çevresi arasındaki etkileşimlerin şekillendirdiği çeşitlilik” olarak tanımlanmaktadır. Bu tanıma göre kültürel peyzajlar; fiziksel çevreye zaman içinde şekil veren ve bugünün peyzajlarını oluşturan kültür ve doğanın karşılıklı etkileşimleri sonucunda oluşmuştur (Fowler 2003).

Parks Canada (1994) "Kültürel Peyzaj" kavramını insanlar tarafindan herhangi bir şekilde değiştirilmiş, etkilenmiş ya da özel kültürel anlamlar yüklenmiş bir coğrafi alan olarak tanımlamaktadır. Melnick ve ark. (1984)'e göre; bir kültürel peyzajda temel faktör kültürdür, zaman içinde doğal peyzajların aracılığıyla ve sonucunda görülen ve deneyim kazanılan peyzaj ortaya çıkmaktadır. Cathy Gilbert (1985)'e göre: kültürel peyzaj insanoğlunun aktivitelerinden etkilenmiş ya da tarihimizdeki önemli bir kişi veya olaya geri plan oluşturmuş herhangi bir coğrafi alan olarak tanımlamıştır.

Bütün bu tanımlar dikkate alınarak kültürel peyzajlar için aşağıdaki tanım yapılmaktadır:
Kültürel peyzaj; kültür ve doğal çevre arasındaki karşılıklı ilişkilerin etkisiyle zaman içinde değer kazanan ve doğal, kültürel, görsel ve anlamsal nitelikleriyle tanımlanabilen ve coğrafi olarak sinırlanabilen bir alandır (Buckle 2002).

Kültürel peyzajlar; kültürel ve doğal kaynakları bir arada bulunduran, evcil hayvanlar veya yaban yaşamının içerisinde yer aldığı, tarihi bir olay, aktivite veya kişi ile bağlantılı olan veya diğer kültürel veya estetik değerlere sahip bir coğrafi alan olarak tanımlanabilir. Kültürel peyzajlar; binlerce hektarlık alanı kaplayan tarım arazilerinden, bir dönümden daha küçük ev bahçelerine kadar değişik ölçeklerde çeşitlilik gösteren alanlardan oluşmaktadır. Arazi formları, toprak yapısı, vejetasyon gibi doğal elemanlar sadece kültürel peyzajın bir parçası olarak kalmayıp, aynı zamanda onun gelişiminin de iskeletini oluşturmaktadır. Kültürel peyzajları oluşturan bu elemanlar onları oluşturan kültürlerin birer aynasıdır (Birnbaum 1996).

Tarihsel süreç içinde kültürel peyzaj dokusu; çevresel faktörlerin değişmesi, insan gereksinimlerinin farklılaşması, teknolojinin ve taleplerin gelişmesine paralel olarak değişime uğramaktadır. Tüm ülkeyi hatta dünyayı etkileyen popüler kültürün yaygınlaşması da yöreye ait elemanların ve kültürel özelliklerin yerini her yerde görülen elemanlara ve manzaralara terk etmesine yol açmaktadır. Zaman içindeki bu değişimin incelenmesi hem kentin fiziksel ve kavramsal değişiminin ortaya konulmasına, hem de 21.yüzyıl insanının yeni gereksinim ve beklentilerinin belirlenmesine olanak sağlayacaktır. Kültürel peyzaj alanlarını etkileyen faktörlerinin araştırılması bu alanların bugünün koşullarına uygun planlanmasina ve tasarımına olanak sağlayacaktır (Özsüle 2005). 


\section{MATERYAL ve YÖNTEM}

\section{Materyal}

$\mathrm{Bu}$ çalışmanın ana materyalini Rize Merkez ilçesi oluşturmaktadır ve çalışma alanı sınırları olarak Rize Merkez İlçesi idari sinırları seçilmiştir. Rize Merkez, Karadeniz Bölgesi'nin Doğu Karadeniz bölümünün kıyı şeridinin doğusunda yer alan Rize ilinin bir ilçesidir. Doğuda Çayeli ve Güneysu ile güneyde İkizdere, batıda Derepazarı ve Kalkandere ilçeleri çevrilidir. Kuzeyde ise Karadeniz ile komşudur. İlçenin Karadeniz'e olan kıyı uzunluğu yaklaşık $20 \mathrm{~km}$. civarındadır. Doğu Karadeniz Bölgesi'nde $40^{\circ} 23^{\prime}$ 55" ve $40^{\circ} 39^{\prime} 12^{\prime \prime}$ doğu meridyenleri ile $40^{\circ}$ $50^{\prime} 20^{\prime \prime}$ ve $41^{\circ} 4^{\prime} 8^{\prime \prime}$ kuzey paralelleri arasında yer alan Rize Merkez'in yüzölçümü yaklaşık 245 km²'dir.

Çalışma alanı kapsamında araştırma, analiz ve değerlendirme sonuçlarına yön veren temel veri kaynaklarının başlıcaları;

- Harita Genel Komutanlığı (HGK) tarafindan üretilen çalışma alanının tümünü kapsayan mevcut tüm hava fotografları olan; 2009, 1989 ve 1955 yıllarına ait $1 / 35000$ ölçekli stereoskopik hava fotoğrafları,

- HGK tarafindan üretilen 2006, 1993 ve 1966 yıllarına ait 1/25000 ölçekli topoğrafik haritalar,

- HGK tarafindan üretilen 1/25000 ölçekli sayısal eşyükseklik haritası,

- Gıda Tarım ve Hayvancilık Bakanlığı tarafindan üretilen 1980 tarihli 1/25000 ölçekli sayısal "Rize Merkez İlçesi Toprak Haritası",

- Orman Genel Müdürlüğü tarafindan üretilen 2006 yılı 1/25000 ölçekli sayısal Rize Merkez İlçesine ait mescere haritas1,
- Rize Valiliği İl Çevre ve Orman Müdürlügüü tarafından hazırlanan 2010 yılı "Rize Çevre Durum Raporu”.

\section{Yöntem}

$\mathrm{Bu}$ çalışmanın amacı, sarp ve engebeli topoğrafik yapısı, endemik bitki türlerini barındıran florası, çay bahçelerinin oluşturduğu tarım dokusu, geleneksel ahşap ve yığma taş evlerden oluşan dağınık yerleşim dokusu ile organik olarak gelişen yöresel bir kültürel peyzaj alanı olarak kabul edilebilecek Rize Merkez ilçesinin geçmişten günümüze kültürel peyzaj dokusunun; arazi kullanım şekilleri ve arazi kullanım örtüsünün nasıl bir değişim geçirdiği ve bu değişimin altında yatan sebeplerin neler olduğunun ortaya konması hedeflenmektedir.

Bu amaçla ilk yöntem olarak Coğrafi Bilgi Sistemleri (CBS) yazılımı ArcGIS 10.1 programı ile çalışma alanının kültürel peyzaj dokusunda geçmişten günümüze ne gibi değişiklikler olduğu tespit edilmiştir.

İkinci yöntem olarak ise, geçmişten günümüze yaşanan bu değişimlerin altında yatan sebepleri ortaya koymak için yerel yöneticiler, kamu kurum ve kuruluşları ile yüz yüze görüşmeler yapılmıştır.

\section{Coğrafi bilgi sistemleri yöntemi}

CBS'nin tanım, içerik ve yetenekleri açısından konuya yaklaşıldığında klasik yöntemler ile yapılan çalışmalara göre bazı avantajlar sağladığı görülmektedir. Bilgi toplama yöntemlerinin çeşitliliği ve güvenilirliği ilk avantajıdır. Aynı işlemlerin tekrar edilmediği, zaman ve emek tasarrufunun sağlandığı, hata payının en aza indirildiği, hataların çok kolay ve hızlı bir şekilde düzeltildiği, bir görüntü yaratma işlemi ile çaba harcanmaksızın o görüntüye ait sayısal ve grafik değerlere ulaşılması, CBS metodolojisini uygulayan 
yazılımın yeteneklerinin sağladığı analiz yöntemleri, hazırlanan dosyaların taşınması, kopyalanması, başka çalışmalara uyarlanması, diğer CBS yazılımlarına çevirim olanağı vb. gibi avantajlar CBS yönteminin tercih edilmesine neden olmaktadır (Turoğlu 2000).

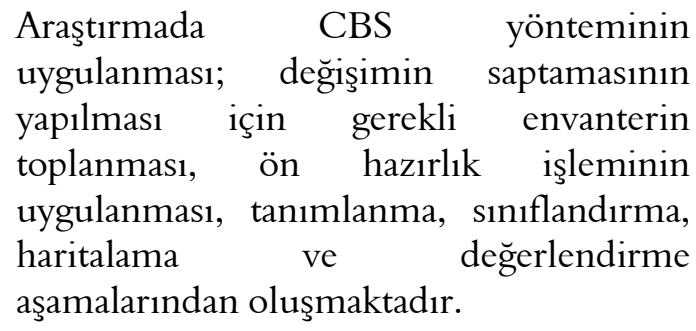

$\mathrm{Bu}$ yönteme göre, ilk olarak HGK tarafindan üretilen 1966, 1993 ve 2004 yıllarını kapsayan 1/25000 ölçekli 24 adet topoğrafik harita taranarak .tiff uzantılı raster formatta bilgisayar ortamina aktarılmıştır. Raster formatındaki topoğrafik haritalar diğer tüm haritalar gibi UTM (Universal Transverse Mercator) koordinat sistemine dönüştürülmüştür. Raster formatındaki bu haritaların her biri CBS kullanılarak köşe koordinatları yardımıla coğrafi olarak konumlandırılarak GeoTIFF formatında kaydedilmiştir. GeoTIFF formatında kaydedilen haritalar 1966, 1993 ve 2004 yılları için ayrı ayrı birleştirilerek, Rize Merkez ilçesinin tamamını kapsayan topoğrafik haritalar elde edilmiştir. Böylece basılı ortamda bulunan topoğrafik haritalar CBS ortamında kullanılabilir ve yorumlanabilir hale getirilmiştir.

HGK'dan elde edilen 1/25000 ölçekli eşyükselti eğrilerini gösteren sayısal (vektör) haritalar birleştirilmiş ve Rize Merkez ilçe sınırlarına göre kesilmiştir. Böylece sadece ilçe sınırlarını kapsayan sayısal eşyükselti haritası oluşturulmuş ve veri tabanına aktarılmıştır. Oluşturulmuş bu haritadan ArcGIS 10.1 kullanılarak Rize Merkez ilçesinin sayısal arazi modeli, yükseklik haritası ve eğim haritası üretilmiştir (Şekil 1).

Daha sonra, Rize Merkez ilçenin tümünü kapsayan mevcut tüm hava fotoğrafları olan; 2009, 1989 ve 1955 yıllarina ait stereoskopik hava fotoğrafları .tiff uzantılı raster formatta HGK'dan temin edilmiştir. Her 3 tarih dilimi için ayrı ayrı olmak üzere, daha önceden koordinatlaması yapilan ve GeoTIFF formatında kaydedilen o yılı ifade eden topoğrafik haritalar ile .tiff uzantılı hava fotoğrafları ilişkilendirilerek koordinatlandırma işlemi yapılmıştır. Koordinatlandırma işlemi için GeoTIFF formatındaki topoğrafik haritalar ile hava fotoğrafları üzerindeki belirgin noktaların karşılıklı olarak eşleştirilmesi yapılmıştır.

Daha sonra, veri tabanının tasarımı gerçekleştirilmiştir. Veri tabanı tasarımı için; söz konusu hava fotoğraflarının çoğunlukla gri renk tonundaki değişim, şekil, büyüklük, desen ve tekstür gibi görüntü karakteristikleri temel alınarak yorumlanmış ve analiz edilmiştir. Amerikan Jeolojik Araştırmalar Merkezi (U.S.G.S) tarafindan hazırlanan arazi kullanım ve arazi örtüsü sınıflandırması (Anderson 1976) dikkate alınarak yapılan yorumlama ve analiz işlemleri sonucunda altı temel arazi kullanım ve arazi örtüsü sınıfinın mevcut olduğu tespit edilmiştir. Arazi kullanım sinıfları olarak; kentsel yerleşim alanı, karayolları, konut-binalar, tarım alanları, arazi örtüsü sınıfları olarak ise hidroloji (akarsu ve dereler) ve orman alanları tespit edilmiştir. Tespit edilen bu sinıfların her birinin verilerinin sayısallaştırma işlemi yapılmıştır. Her 3 tarih dilimi için ayrı ayrı oluşturulan alan kullanım / arazi örtüsü sinıflandırması sonucunda vektör haritaları ve öznitelik tabloları oluşturulmuştur. Elde edilen bilgiler veri tabanına girilmiş çözümleme ve sorgulamaya hazır konuma getirilmiştir. 

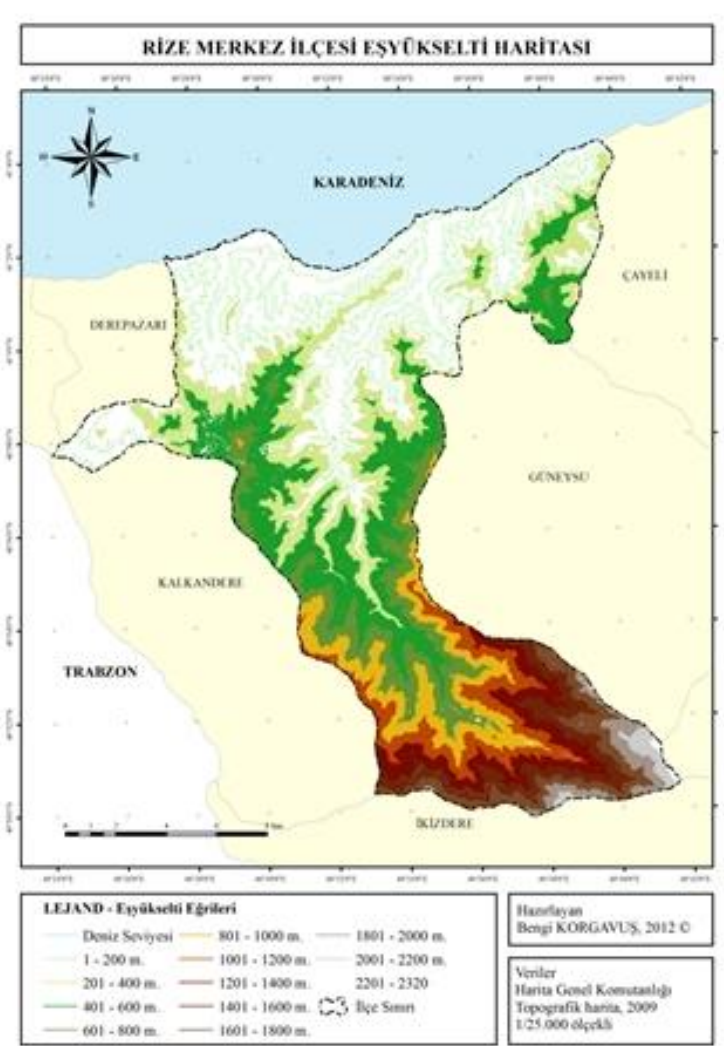
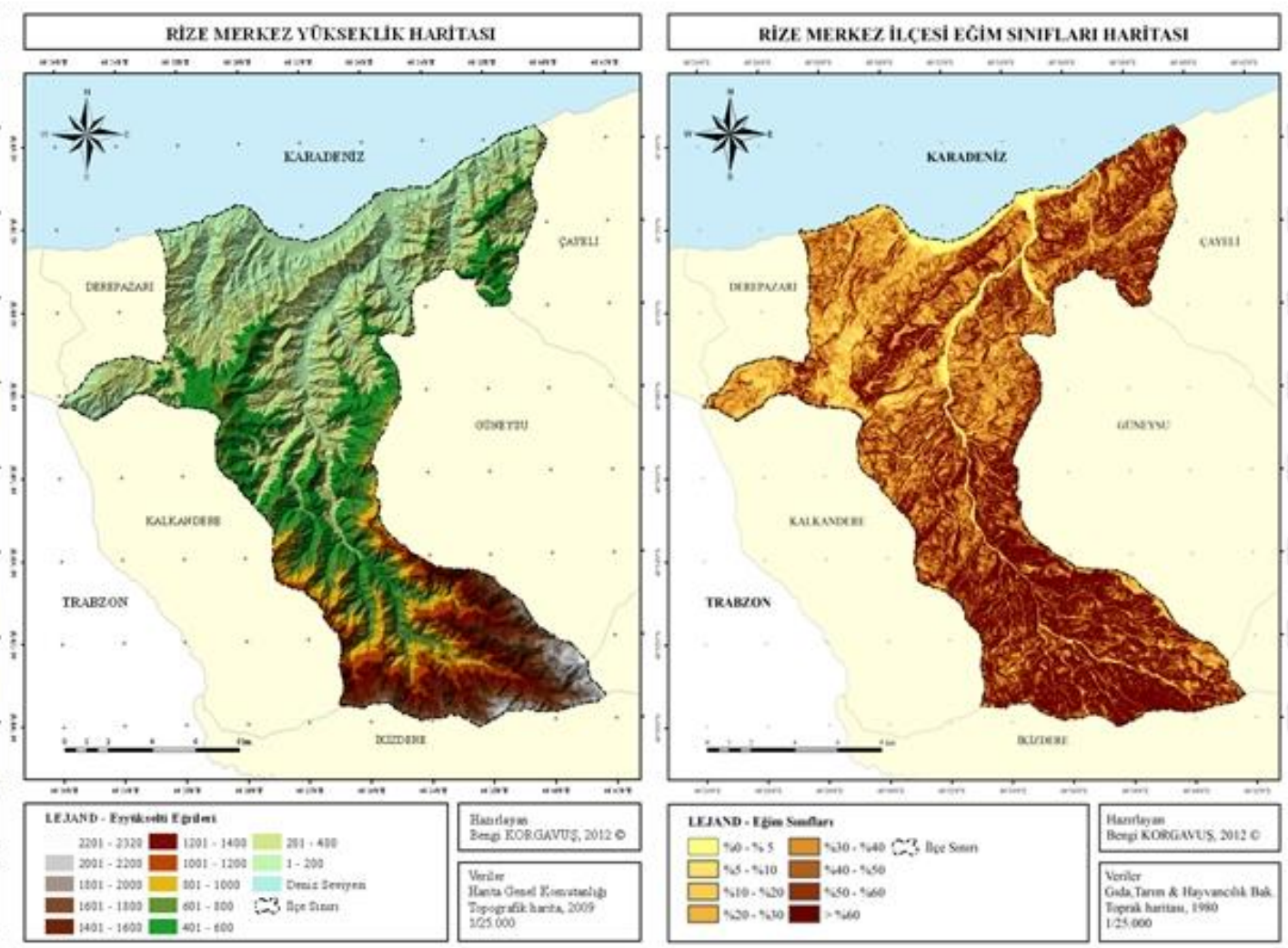

Şekil 1. Rize Merkez ilçesi eşyükselti, sayısal yükseklik ve eğim haritası. 
2009, 1989 ve 1955 yıllarına ait hava fotoğraflarından sayısallaştırılan karayolları, kentsel yerleşim alanı, konut ve bina adetleri, orman alanları ve tarım alanları verileri birbirleriyle karşılaştırılarak yıllar arası değişimi gösteren arazi kullanım şekillerinin ve arazi örtülerinin nitelikleriyle nicelikleri ortaya konmuştur. $\mathrm{Bu}$ şekilde 54 yillık süreç içerisinde meydana gelen değişimler ortaya konulmuştur.

\section{Yüz yüze görüşme yöntemi}

Çalışmada ikinci yöntem olarak, Rize Merkez ilçesinin sosyo-ekonomik yapısı ve 1955 y1lından buna yana meydana gelen çevresel değişimlerin altında yatan sebeplerin ortaya konması amacı ile yerel yöneticiler, kamu kurum ve kuruluşları ile yüz yüze görüşmeler yapılmıştır. $\mathrm{Bu}$ amaçla; Rize Merkez Tarımsal Kalkınma Kooperatifi, Rize Ticaret Borsası, Rize Ziraatçılar Derneği, Rize Ziraat Mühendisleri Odası, Rize Ziraat Odası, Rize Kivi Birliği, Çay-Koop Merkez Birliği, Çaykur Cumhuriyet Çay Fabrikası, Rize Tarım İl Müdürlüğü, Maviyemiş Likapa Derneği, Ulusal Fındık Konseyi ile görüşmeler yapılmıştır. Görüşme yapılan profil; sektörle ilgili oldukları, sektöre yön verdikleri, sektörle ilgili üreticilerle doğrudan yada dolaylı ilişkide oldukları, üreticilerin nabzını tuttukları; ürün veya ürünlerle ilgili öncü, yol gösterici veya yetkin oldukları için tercih edilmiştir.

Katılımcılara uzmanlık alanlarına göre çay (Camellia sinensis), kivi (Actinidia sp.), maviyemiş (Vaccinium sp.) yâda findık (Corylus sp.) gibi tarımsal ürünlerin üretimi ile ilgili açık uçlu sorular sorulmuştur. Soru sayısı her bir tarımsal ürün için 17 ile sınırlandırılmıştır.

Yapılan görüşmelerin içeriğini; Rize'nin ekonomisinin temelini oluşturan çay tarımın günümüzdeki durumu, yaşanan zorluklar, üreticilerin çaya olan bakış açısı, alternatif tarımsal ürün arayışlarının sebepleri, üretimine yeni başlanan kivi, maviyemiş gibi ürünlerin Rize'de yetiştirilme fikrinin nasıl ortaya çıktığı ve günümüzdeki üretim durumları ve halkın bu ürünlere karşı olan tutumu olarak nitelendirebiliriz.

\section{BULGULAR}

1955, 1989 ve 2009 ylllarina ait hava fotoğraflarının ve diğer sayısal olmayan verilerin sayısallaştırılması, yorumlanması ve analiz edilmesi sonucunda aşağıda ki bulgulara ulaşılmıştır.

\section{Karayolları}

Karayolları sinıflandırılması sert satıhlı yollar ve ham yollar olarak ikiye ayrilarak incelenmiştir. Rize Merkez'de 1955 yılında toplam karayolu ağı 759731 metretul (mt), 1989 yllında 907874 mt, 2009 yılında 1184212 mt'dür. Bu 1184212 mt yolun sadece \%13'ü sert satıhlı yollardan, geri kalan \%87'si ise ham yollardan oluşmaktadır (Tablo 1) (Şekil 2). Ham yolların bu kadar fazla olmasinın sebebi topoğrafik yapı ve dağınık yerleşim şeklinden kaynaklanan yol talebindeki artıştır.

Tablo 1. Rize Merkez ilçesi 1955-2009 yılları arasında karayolları ağı

\begin{tabular}{|c|c|c|c|}
\hline \multicolumn{4}{|c|}{ Sert Satıhlı Yollar } \\
\hline & 1955 & 1989 & 2009 \\
\hline Bölünmüş Yol & - & - & $19813 \mathrm{mt}$ \\
\hline $\begin{array}{l}\text { Çift Şeritli } \\
\text { Yol }\end{array}$ & $43194 \mathrm{mt}$ & $72865 \mathrm{mt}$ & $74811 \mathrm{mt}$ \\
\hline $\begin{array}{l}\text { Yerleşim İçi } \\
\text { Yol }\end{array}$ & $12129 \mathrm{mt}$ & $30345 \mathrm{mt}$ & $54923 \mathrm{mt}$ \\
\hline Toplam & $55323 \mathrm{mt}$ & $103210 \mathrm{mt}$ & $149547 \mathrm{mt}$ \\
\hline \multicolumn{4}{|c|}{ Ham Yollar } \\
\hline $\begin{array}{l}\text { Daimi Araç } \\
\text { Yolu }\end{array}$ & $15666 \mathrm{mt}$ & $192493 \mathrm{mt}$ & $262854 \mathrm{mt}$ \\
\hline Yaz Araç Yolu & $168144 \mathrm{mt}$ & $302147 \mathrm{mt}$ & $646118 \mathrm{mt}$ \\
\hline Patika Yol & $520598 \mathrm{mt}$ & $310024 \mathrm{mt}$ & $126574 \mathrm{mt}$ \\
\hline Toplam & $704408 \mathrm{mt}$ & $804664 \mathrm{mt}$ & $1035546 \mathrm{mt}$ \\
\hline $\begin{array}{l}\text { Genel } \\
\text { Toplam }\end{array}$ & $759731 \mathrm{mt}$ & $907874 \mathrm{mt}$ & $1185093 \mathrm{mt}$ \\
\hline
\end{tabular}



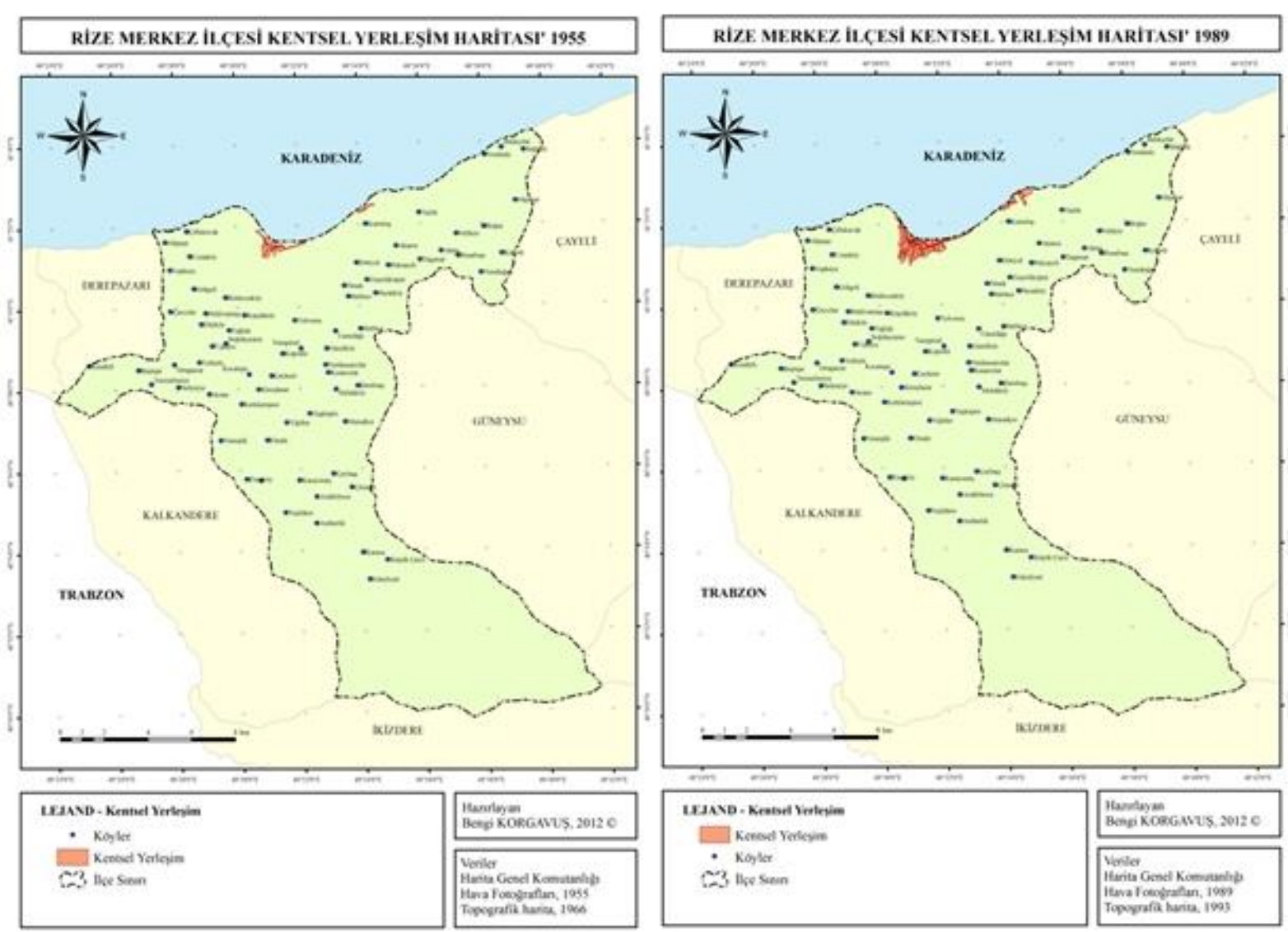

RIZE MERKEZ ILCCESI KENTSEL. YERL.FSIM HARITASI' 2009

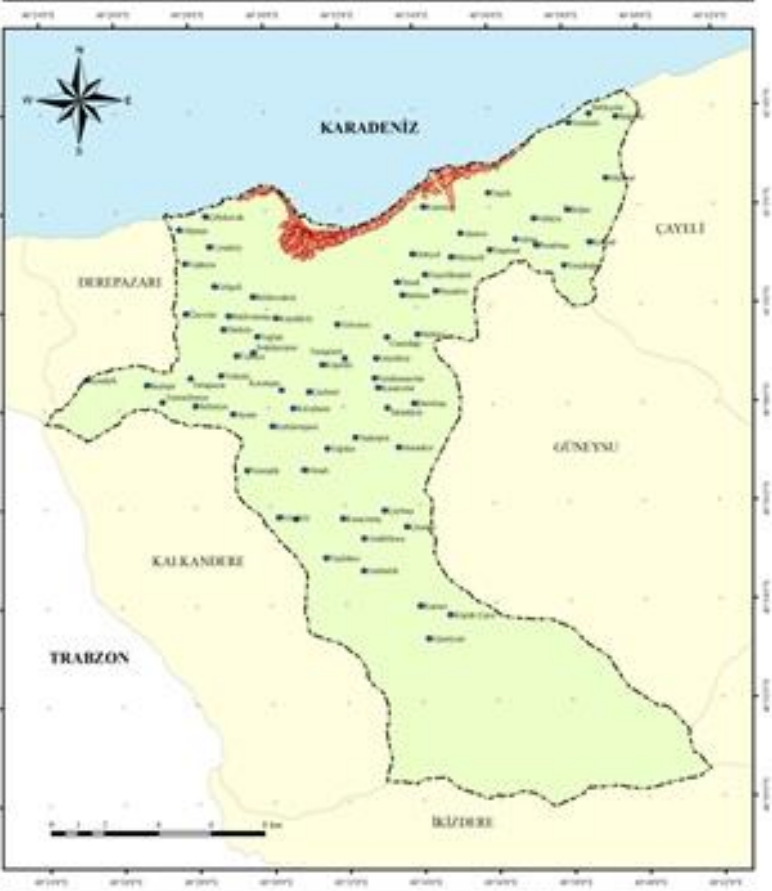

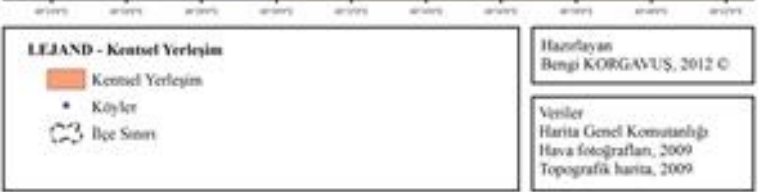

Şekil 2. Rize Merkez ilçesi 1955, 1989 ve 2009 yılları karayolları ağı. 


\section{Kentsel Yerleşim Alanı}

Rize Merkez ilçesinde coğrafi koşulların çok sert oluşu özellikle yerleşmeler açısından kısıtlayıcı ve belirleyici bir unsur olarak ortaya çıkarmaktadır. Dağlar denizden hemen sonra yükselmeye başlamakta, bu sebeple kıyılarda ve iç kesimlerde kurulan yerleşmeler birbirlerinden keskin çizgilerle ayrilmakta ve iki farklı doku oluşturmaktadır.

Nüfus yoğunluğu, kıyı kesimlerinde, yüksek dağların izin verdiği ölçüde vadilerde ve ovalarda daha fazladır. Buna paralel olarak kentsel işlevler (yönetim, ticaret, zanaat) kıy kesimlerinde yoğunlaşmaktadır. Günümüzde kıyı kesimi iç kesimlerden göç almaktadır. Kıyı kesimlerinde ki yerleşmelerinin eski karakteri bahçeli evlerin yan yana geldiği seyrek yerleşim dokusu iken, zamanla ticaret ve hizmet sektörlerinin çoğalmasıyla binalar sıklaşmış, yükselmiş ve bitişik yerleşme düzenine dönüşmüştür. 1955 yılında 59 ha olan kentsel yerleşim alanı 1989 yılında 210 ha, 2009 yilında ise 452 ha olmuştur (Şekil 3.).

\section{Konut ve Binalar}

Topoğrafik yapı gereği iç kesimlerde yerleşmeler kıyıdaki yerleşmelerin aksine genellikle yamaçlarda, dağınık şekilde, kümeler halinde, küçük ve birbirinden kopuk olarak gelişmiştir. Yerleşmelerin dağınıklığının öncelikli nedeni engebeli topografya nedeni ile tarım alanlarının çok parçalı olması, yörede her ailenin 0.3-0.5 ha'dan 15-20 ha'a kadar çeşitli büyüklüklerde araziye sahip olmasıdır.

Buna bağlı olarak tarımın yerleşikliğe bağlı bir olgu olması nedeniyle tarlayı ve bahçeyi ekip bakımını yapmak için evini kendi arazisi içinde kurma isteğidir.
1955 yılında kamu binaları, okullar, çay atölyeleri, evler vb. dâhil toplam 10361 adet bina bulunurken bunun 431 adedi kentsel yerleşim alanında geri kalan 9930 adedi ise kırsal peyzajda dağınık yerleşim şeklinde yer almaktadır. 1989 yılında bina sayısı 16372 adede çıkmıştır. Bunun 996 adedi kentsel yerleşim alanında, 15376 adedi kırsal yerleşim alanında yer almaktadır. 2009 yılında ise 18534 adet binanın 2176 adedi kentsel yerleşim alanında, geri kalan 16358 adedi kırsal alanda yer almaktadır (Tablo 2) (Şekil 4).

Tablo 2. Rize Merkez ilçesi 1955-2009 yılları arasinda bina adetleri.

\begin{tabular}{|c|c|c|c|}
\hline Bina Adedi & 1955 & 1989 & 2009 \\
\hline Kentsel Yerleşimler & 431 & 996 & 2176 \\
\hline Kırsal Yerleşimler & 9930 & 15376 & 16358 \\
\hline Toplam & 10361 & 16372 & 18534 \\
\hline
\end{tabular}

Rize Merkez ilçesi nüfusu 135148 kişidir. Nüfusun 96503 kişisi şehirde yaşarken, 38645 kişisi belde ve köylerde yaşamaktadır. Nüfusun \%71'i kentsel yerleşim alanında yaşamaktadır (TUİK 2009). Çok dar olan kıyı bandında bu kadar büyük bir nüfusun yaşaması buradaki kentsel yerleşim dokusunun kesintisiz birbirinin devamı şeklinde ve çok katlı yapılardan oluşmasına sebep olmaktadır. Kırsal kesimde nüfusun sadece \%29'u yaşamasina ve kent merkezine doğru sürekli göç etmesine rağmen; kırsal kesimdeki bina sayılarında beklenenin tersine hızı giderek azalan rutin bir artış gerçekleşmiştir. Bu artışın sebebi kentsel yerleşmelere göç edenlerin memleket özlemi, baba ocağı ve tatil gibi çeşitli sebeplerden dolayı kırsal alanlarla bağlarını koparmaması ve özellikle yazları kalabilecekleri ikinci bir konuta sahip olmalarıdır (Reis ve ark. 2009). 

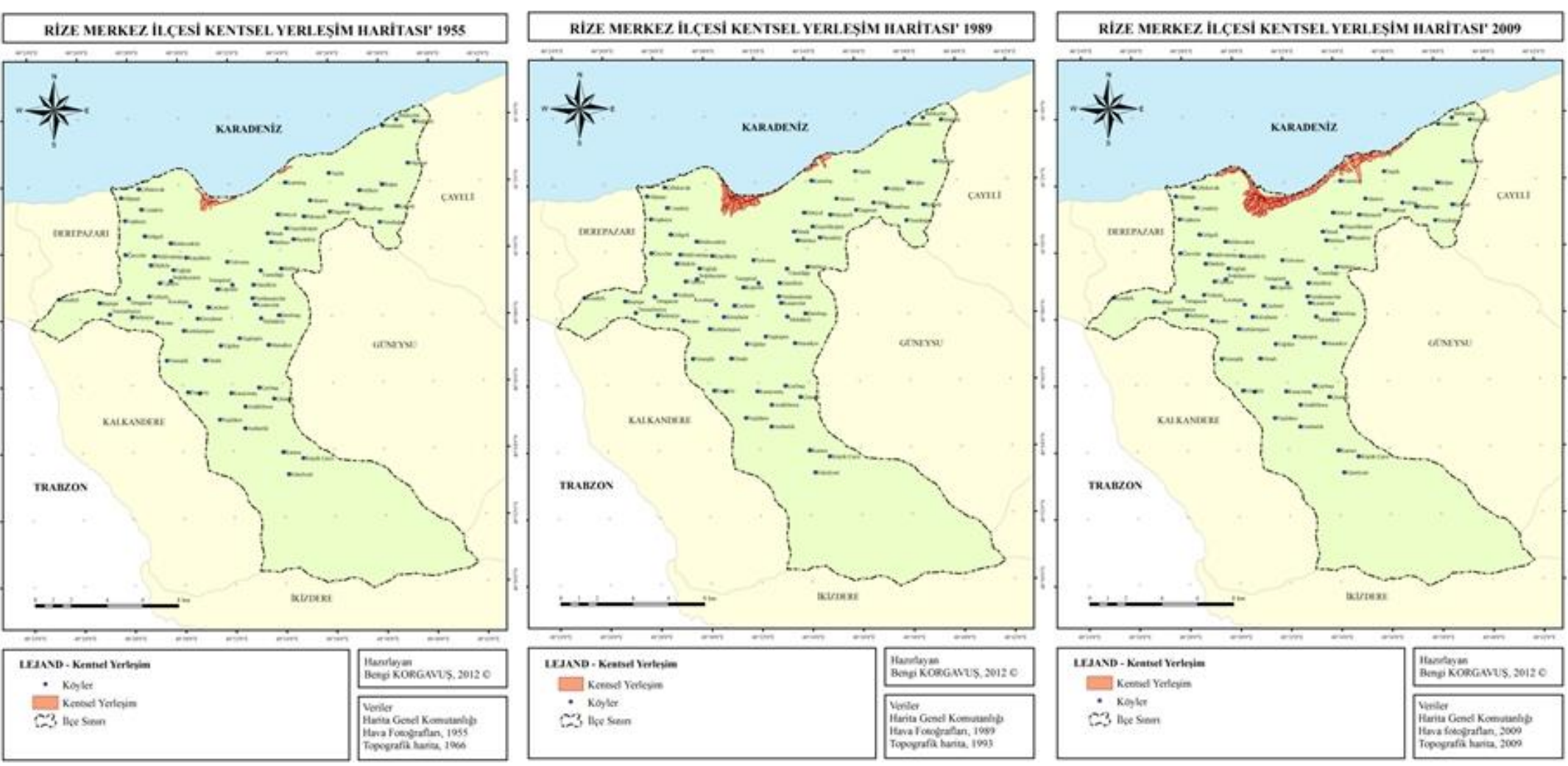

Şekil 3. Rize Merkez ilçesi 1955, 1989 ve 2009 yılları kentsel yerleşim alanları. 

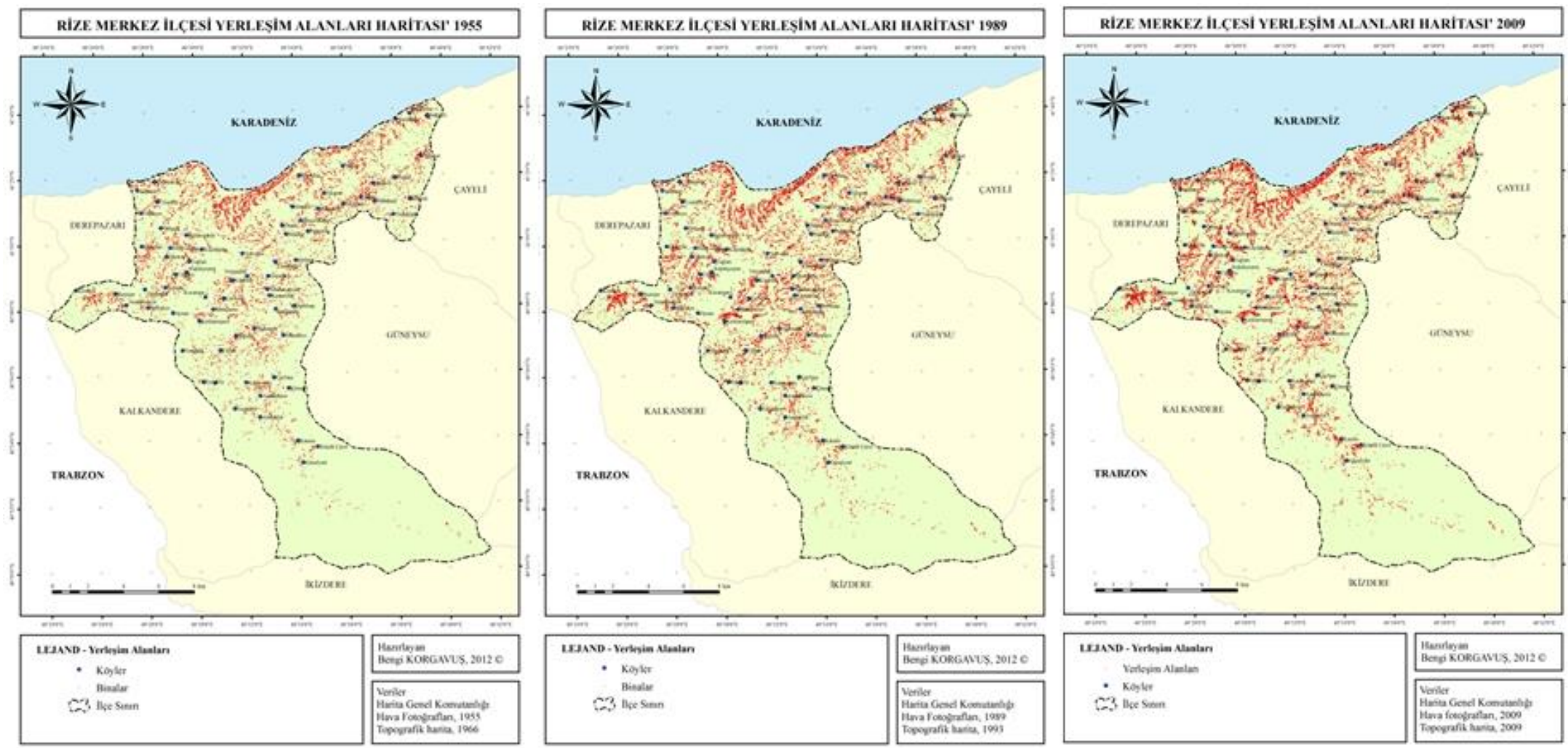

Şekil 4. Rize Merkez ilçesi 1955, 1989 ve 2009 yılları yerleşim alanları ve binalar. 


\section{Akarsu ve Dereler}

Rize'nin bol yağışlı iklim tipi ve çok sayıda yeraltı su kaynakları sayesinde çok zengin bir doğal su varlığına sahiptir. Rize sınırları içinde doğu-batı yönünde ortalama her 250-300 m'de büyük veya küçük bir akarsuya mutlaka rastlanır. Nitekim arazinin rölyefi de bunu göstermektedir. Rize Merkez ilçesinde yer alan derelerin bazıları yıllar içerisinde doğal olarak kurumuş, bazıları ise yerleşim alanlarının içinde kaldığı için üzerleri kapatılarak yüksek yoğunluklu yapı alanları için kazanılmıs alan olarak kullanılmaya başlamıştır. 1955 yılında 326976 metretul (mt) sulu dere, $356218 \mathrm{mt}$ kuru dere olmak üzere toplam $683194 \mathrm{mt}$ dere bulunmaktaydı. 1989 yılında bu derelerin 4974 mt'ünün üzeri kapatılarak, toplam dere miktarı; 323848 mt'ü sulu dere, 354372 mt'ü kuru dere olmak üzere 678220 mt'e inmiştir. 2009 yllında ise $7664 \mathrm{mt}$ derenin daha üzeri kapatılarak toplam dere miktarı 670556 mt'e, sulu dereler ise 264432 mt'e inmiştir. Ayrıca $51751 \mathrm{mt}$ dere doğal yollarla kuruyarak kuru dere miktarı 406123 mt'e çıkmıştır (Tablo 3) (Şekil 5).

Tablo 3 Rize Merkez ilçesi 1955-2009 yılları arasında akarsu ve dereler.

\begin{tabular}{|c|c|c|c|}
\hline Akarsu ve Dereler & 1955 & 1989 & 2009 \\
\hline Sulu Dere & $326976 \mathrm{mt}$ & $323848 \mathrm{mt}$ & $264432 \mathrm{mt}$ \\
\hline Kuru Dere & $356218 \mathrm{mt}$ & $354372 \mathrm{mt}$ & $406123 \mathrm{mt}$ \\
\hline Toplam & $683194 \mathrm{mt}$ & $678220 \mathrm{mt}$ & $670556 \mathrm{mt}$ \\
\hline
\end{tabular}

\section{Orman Alanları}

Rize Merkez ilçesi sahip olduğu iklim yapısı ile geniş ormanlık alanlara sahiptir. Bölgenin yaz ve kış aylarında bol yağış alması orman örtüsünün geniş ve gür olmasını sağlamıştır. Kıyıdan $750 \mathrm{~m}$ rakıma kadar geniş yapraklı kıyı ormanları, 800-1400 m rakıma kadar geniş yapraklı ve ibreli türlerin bir arada bulunduğu karışık ormanlar, 1600 m rakımdan 2000-2200 m rakıma kadar ibreli ormanlar görülmektedir. Rize Merkez ilçesinde ormanlar yaklaşık olarak 2000-2200 m yüksekliklerde sona erer ve yerini alp çayırlarına bırakır. Rize'de arazilerin çok engebeli olması, toplam arazi varlığının büyük kısmının orman ve koruluk olması nedeniyle tarım yapılabilecek arazi miktarı çok azdır. Yöre halkının en önemli geçim kaynağını ise çay tarımı oluşturmaktadır. $\mathrm{Bu}$ yüzden orman arazileri halk tarafindan tahrip edilerek çay bahçelerine dönüştürülmektedir. 1955 yllında Rize Merkez ilçesinde 15996 ha orman arazisi bulunurken, 1989 orman alanları 12257 ha'a inmiştir. 2009 yllında ise orman alanları 9503 ha'a inmiştir (Şekil 6). Orman alanlarının bu şekilde gelişi güzel açılması ve bitki örtüsünün tahrip edilmesi; doğal kaynakların bilinçsizce tüketilmesine, ekolojik dengenin bozulmasına, toprak veriminin azalmasına, heyelanların ve sellerin artmasina sebep olmaktadir. 

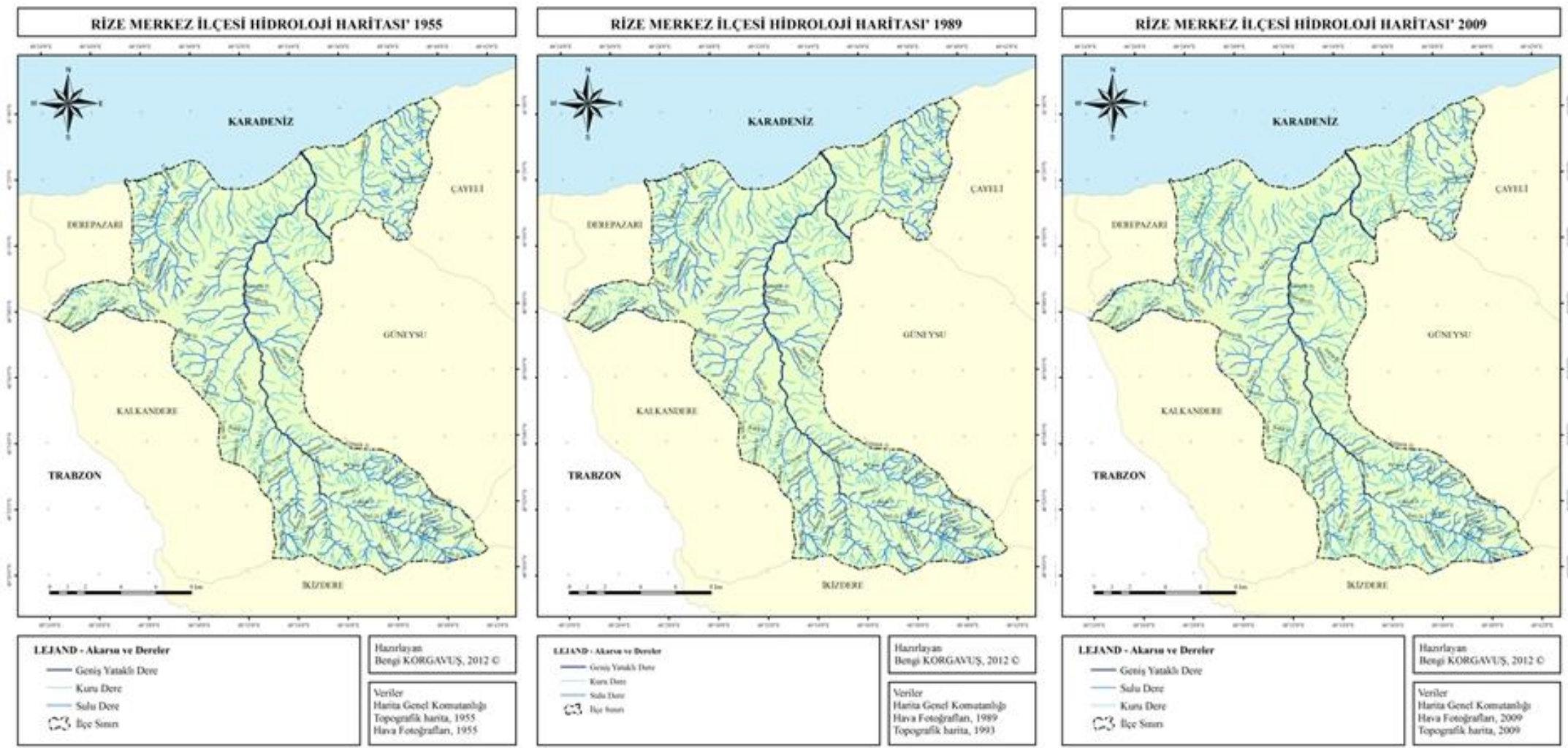

Şekil 5. Rize Merkez ilçesi 1955, 1989 ve 2009 yılları akarsu ve dereler. 

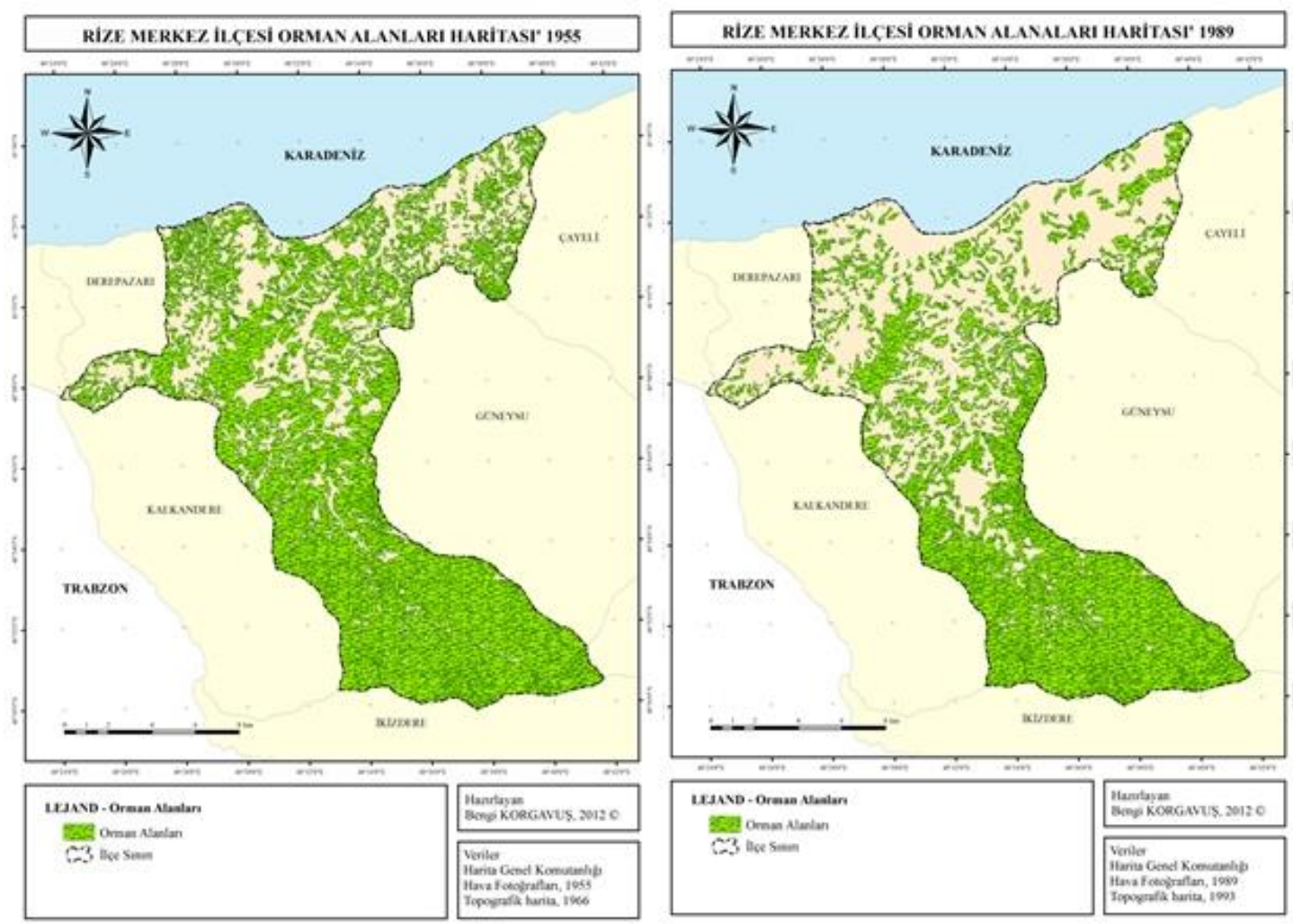

RIZE MERKEZ ILCESI ORMAN ALANLARI HARITASP 2009
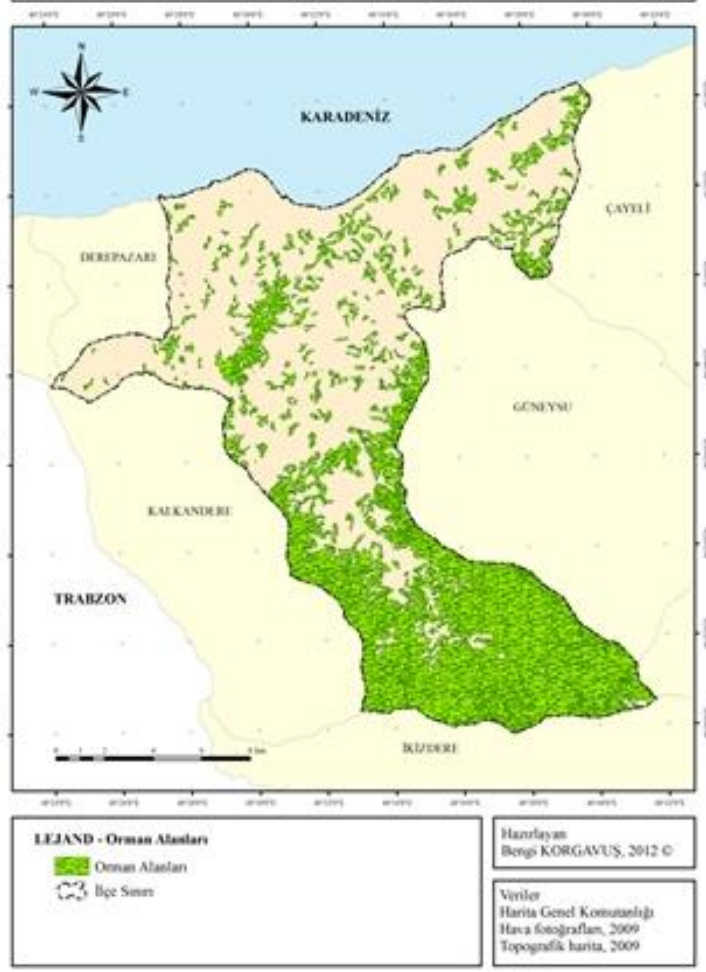

Şekil 6. Rize Merkez ilçesi 1955, 1989 ve 2009 yılları orman alanları. 


\section{Tarım Alanları}

1938 yılında ilk olarak çalılık, fundalık ve kızılağaçlık halindeki topraklarda, mısır tarımına ek gelir olarak başlanan çay tarımı yörede hızla gelişerek geleneksel bir tarım ürünü haline gelmiştir. Günümüzde ilçenin ekonomisine de, ticaretine de çay bitkisi ve çay tarımı damgasını vurmakta ve yöre halkının en önemli geçim kaynağını oluşturmaktadır. Çay bahçeleri, ilçenin ekili alanlarının büyük bir bölümünü kapladıktan sonra tüm kıy boyunca gelişerek, tarıma elverişli olmayan iç kesimlerdeki yamaçlara da uzanmıştır (Tablo 4). Bölgede yaşanan arazi kıtllğ 1 nedeniyle orman arazileri de zamanla yöre halkı tarafindan çay bahçelerine dönüştürülmüsstür.

Bölgede çay dışındaki tarımsal nitelikteki alanlar doğrudan gelir getirmekten ziyade mevsimsel ihtiyaçları karşılamak amacıyla oldukça küçük alanlarda iç içe veya çay bahçelerinin içerisinde olacak şekilde yapılmaktadır. Ayrıca bu alanların yöre halkının ikamet ettikleri evlere yakın ve çok küçük bahçeler şeklinde olduğu görülmektedir. $\mathrm{Bu}$ nedenle hava fotoğraflarından sayısallaştırma işlemi yapılırken bu tür bahçelerin tespiti net olarak yapılamadığı için çay ve varsa findık dışında kalan tarım alanları ayrı bir grup olarak sınıflandırmaya dâhil edilememiştir.

Rize Merkez ilçesinde 1955 yılında tarım alanları 8496 ha, 1989 yilında orman arazileri içinde yeni tarım alanlarının açılması ile 11928 ha'a, 2009 yllında ise 13824 ha'a çıkmıştır. Tarım alanlarının çok büyük bir kısmını çay bahçeleri oluşturmaktadır (Şekil 7). Fındık üretimi ise Rize Merkez ilçesinde yok denecek kadar azdir ve ekonomik bir gelir elde etmekden daha ziyade her ailenin kendi ihtiyacinı karşılayacak düzeyde yapılmaktadır.

Tablo 4. Rize Merkez ilçesi arazi kullanım kabiliyet sınıflarına göre tarım alanları.

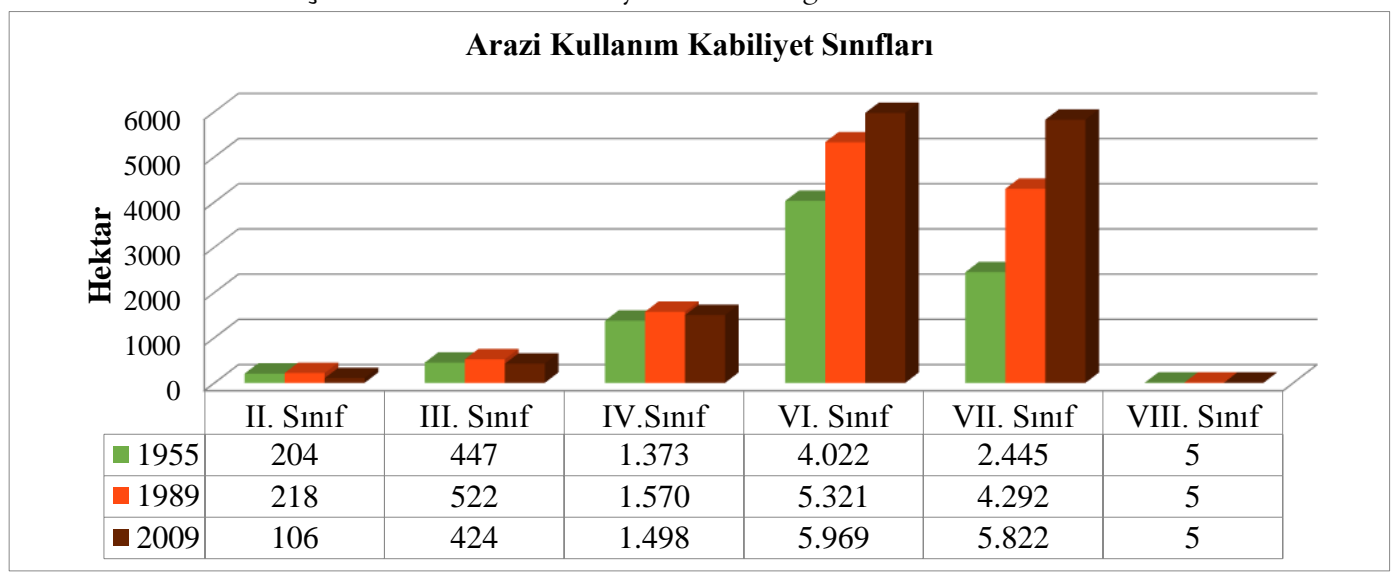



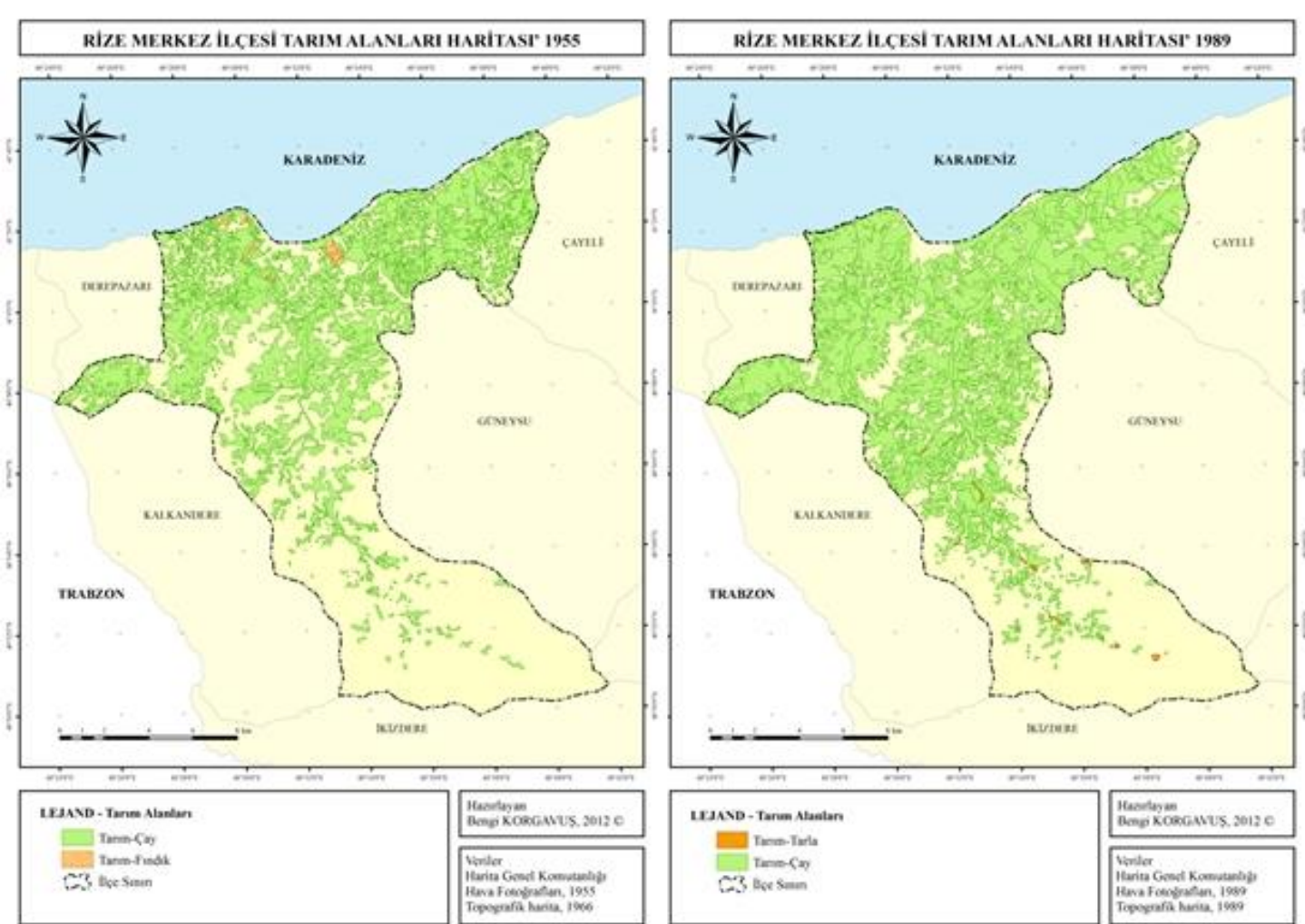

RIZE MERKEZ ILCCESI TARIM ALANL.ARI HARITASP 1989

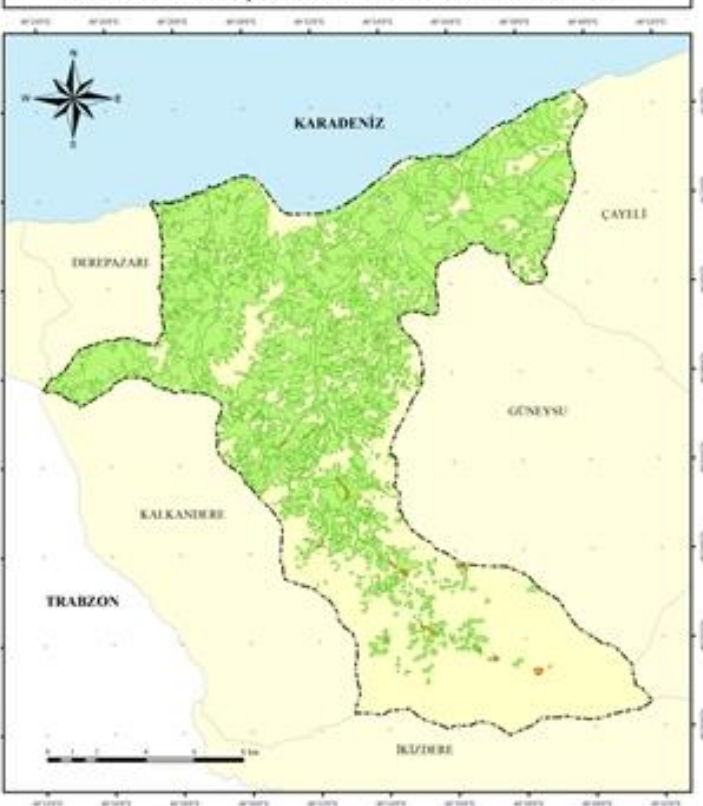

STD-Tamentad

Cos Bosen

\section{RIZE MERKEZ ILCESI TARIM ALANLARI HARITASI' 2009}

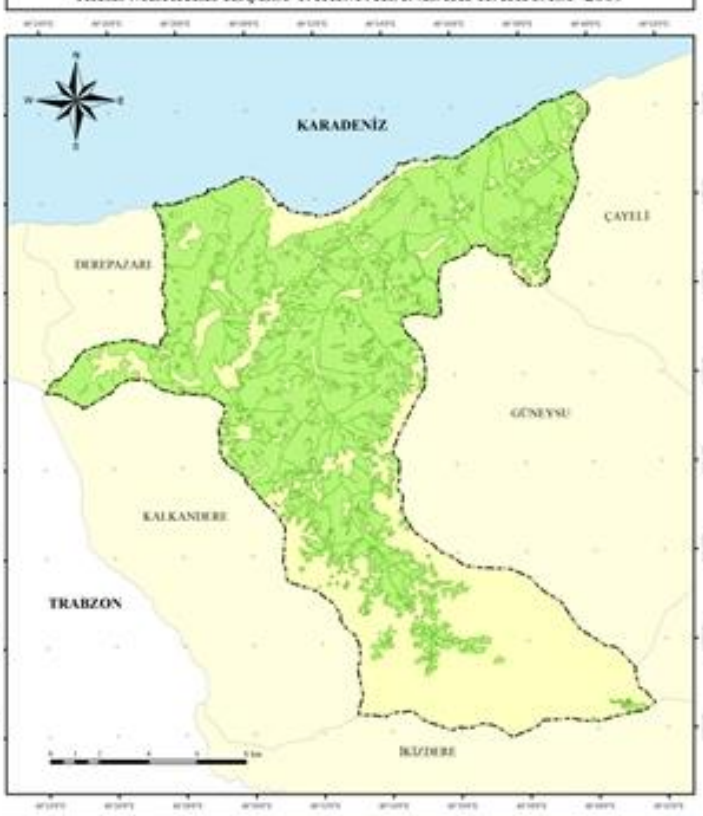

\begin{tabular}{|c|c|}
\hline \multirow{2}{*}{ 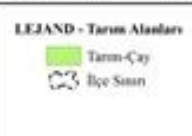 } & 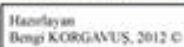 \\
\hline & 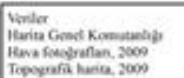 \\
\hline
\end{tabular}

Şekil 7. Rize Merkez ilçesi 1955, 1989 ve 2009 yılları tarım alanları. 


\section{Görüşmelerden Elde Edilen Bulgular}

- Çaykur, çay tarım alanlarının genişlemesini önleyebilmek ve kaliteli yaş çay yaprağı satın almak amacıyla, 2000 yılından itibaren yaş çay alımlarında kota uygulamasına geçmiştir. Bu uygulama ile bölgede yeni çaylık tesis edilmesinin önüne geçilmeye çalışılmakta, ruhsatlı üreticilerin üreticilik hakları korunmaya çalışılmaktadır.

- Bölgede çay tarımı yapan üreticilerin genel karakteristiği küçük aile işletmeciliği şeklinde olup, üreticilerin \% 80'i 5 dekar ve 5 dekarın altında çay bahçelerine sahiptir. Zaten küçük olan arazilerin miras yolu ile daha da bölünmesi, ekim alanlarının artmasıyla iç tüketimden fazla üretim yapılması, Çaykur tarafindan kota uygulaması konması, kalan ürünün özel sektör tarafından çok ucuza alınması, yarıcı tabir edilen işçilerin mahsulün yarısına ortak olması gibi nedenlerden ötürü çayın ekonomik getirisi yıllar içinde çok düşmüştür. Halk son yıllarda $\mathrm{m}^{2}$ 'de çaydan daha çok getirisi olan alternatif ürün arayışlarına girmiştir fakat iklim, topoğrafik yapı ve diğer faktörler nedeni ile kayda değer ekonomik getirisi olan, çaya alternatif başka tarım ürünlerinin üretimi Rize'de mümkün olamamaktadır. Son yillarda üretimine başlanan kivi, maviyemiş, narenciye, siyah üzüm vb. gibi ürünler ise çaya alternatif değil, sadece çayın yanına ek bir gelir olarak düşünülebilir.

- Rize Merkez ilçesinde çaydan sonra üretimi en çok yapilan ve ekonomik getirisi çaydan daha fazla olan ek tarım ürünü kividir. Kivi tarımı bölgede 1994 yılında başlamış ve hızla artmıştır. Arazi yetersizliği nedeniyle kivi üretimi, çay bahçelerinin içlerinde ve küçük alanlarda yapilmakta, tesis kurulum maliyetinin yüksek olması, bakım gereksinimleri, soğuk hava deposu eksikliğinden dolayı ve hasattan hemen sonra satılma gereksinimi kivi üretiminin artışını olumsuz yönde etkilemektir.

- Bölge tarımına ürün çeşitliliği açısından en büyük katkıyı sağlayacak olan bir diğer ürün olarak ise maviyemiş göze çarpmaktadır. Doğu Karadeniz'in yüksek dağ ve yaylalarında yabani olarak yetişen maviyemişin kültür olarak yetiştiriciliği çok yenidir. Bahçe tesis maliyetinin ve fidan bedelinin yüksek olması, bakım gereksinimleri, ürünlerin toplanmasının zahmetli olması, ulaşım, depolama ve pazarlama zorluğu gibi sebepler yüzünden günümüzde maviyemiş üreticiliği çok azdır. Yüksek rakımlarda çay tarımı veriminin düşük olduğu ekilebilir tarım arazilerinden kullanılmayan ve çayırlık olarak terk edilmiş, yamaçlı araziler maviyemiş bahçeleri olarak değerlendirilebilmektedir. Hem de bu şekilde terk edilmiş kullanılmayan araziler bölge ekonomisine kazandırılmış olacaktır.

\section{TARTIŞMA VE SONUÇ}

Rize Merkez ilçesi gibi sürekliliği olan dinamik kültürel peyzaj alanları, organik olarak geliştikleri, halkın yaşam tarzı ve aktivitelerine göre şekillendikleri için zaman içerisinde yine toplumun gelişen istek ve ihtiyaçlarına veya doğal çevre faktörlerine bağlı olarak değişim ve gelişim göstermektedir. Bu nedenle arazi örtüsü ve kullanımında zaman içerisinde oldukça fazla miktarda değişim meydana gelmektedir. Yöre insanı yaşamını devam ettirebilmek için doğanın olumsuz etkilerini kendi lehine çevirmek üzere sürekli mücadele vermiş ve bu mücadele günümüzde de devam etmektedir. Nitekim bu çalışmada da Rize Merkez ilçesinde kültürel peyzaj alanlarındaki değişim değerlendirildiğinde, arazi kullanım şekilleri ve arazi örtüsü sınıflarının yıllar içerisinde halkın artan ihtiyaçları doğrultusunda şekillendiği 
görülmektedir. Başta konut ve yiyecek olmak üzere birçok ihtiyaç nedeniyle, kültürel peyzaj alanları kontrolsüz bir şekilde tahrip olmaktadır. Nüfus ve ekonomik ihtiyaçlar arttıkça, kentsel alanlar, yapılar, karayolları ve tarım alanlarında artış görülmektedir. Buna karşılık başta orman alanları olmak üzere akarsu ve derelerde azalma görülmektedir.

Rize Merkez ilçesinin sahip olduğu engebeli, çok hareketli topografya ve iklim şartları yöreye farklı bir karakter kazandırmıştır. Günden güne yayılıp, bahçeleri yamaçları kaplayan çay bahçeleri bir yandan Rize insanının yaşam biçimini dönüştürürken, bir yandan da nesillerin tüketim tercihinde önemli bir rol almaktadır. Çayın ilçeye gelmesiyle başlayan değişim ve gelişim halen farklı şekillerde devam etmektedir.

Rize halkı için çay her ne kadar ekonomik olarak iyi bir gelir getirmese de vazgeçilmez durumdadır. Çay artık özelde Rize'ye, genelde ise tüm Türkiye'ye mal olmuş milli bir değer ve bir kültürdür. Çay tarımının sağlıklı bir şekilde gelecek kuşaklara aktarılması ve ekonomik değerlerinin korunması için yapılması gereken çalışmaların başında; mevcut çay tarımının geliştirilmesi, verim ve kalitenin yükseltilmesi gelmektedir. Ayrıca iklim ve toprak uygunluğu göz önüne alınarak, tarımsal ürün çeşitliliğinin arttırılması ve tek ürüne mahkûmiyetin ortadan kaldırılması gerekmektedir. Kivi ve maviyemiş bu konuda bölgeye en uygun ve ekonomik getirisi yüksek olan ek tarım ürünleridir.

Sonuç olarak yöre halkının en önemli geçim kaynağı olan çay bahçeleri yıllar içerisinde özellikle ormanlık alanları açılarak genişletilmiştir. Çay bahçelerindeki bu artış bölge halkının ekonomik olarak bu tarım ürününe olan bağımlılığından kaynaklanmaktadır.
Dolayısı ile buradan sosyo-ekonomik faktörlerin kültürel peyzaj alanlarını etkileyen en önemli faktör olduğu sonucuna varılmaktadır.

Kültürel peyzaj alanlarındaki tüm değişimlerin belirlenmesi ve izlenmesinde Coğrafi Bilgi Sistemlerinin önemi ortaya çıkmaktadır. Hava fotograflarının ve diğer verilerin Coğrafi Bilgi Sistemlerinde analiz edilmesi ile zamansal değişimler ve istatiksel analiz sonuçları klasik yöntemlere göre çok kısa sürede ve doğru bir biçimde rahatlıkla yapılabilmektedir.

\section{KAYNAKLAR}

Anderson JR (1976) A land use and land cover classification system for use with remote sensor data: Geological Survey Professional Paper 964. http://landcover.usgs.gov/pdf/anderson.pdf (Erişim Tarihi: 7 Mart 2014)

Anonim (2003) ArcGIS. İşlem Coğrafi Bilgi Sistemleri ve Eğitim Ltd. Şti, Ankara.

Birnbaum CA (1996) USNPS preservation brief 36: Protecting Cultural Landscapes: Planning, Treatment and Management of Historic Landscapes. http://www.nps.gov/tps/how-topreserve/briefs/36-cultural-landscapes.htm (Erişim Tarihi: 7 Mart 2014)

Buckle RJ (2002) Managing cultural landscapes: A case study of Stirling, Alberta. University of Calgary Master Tezi, Canada, $90 \mathrm{~s}$.

Fowler PJ (2003) UNESCO World Heritage Cultural Landscapes 1992-2002 World Heritage series papers Vol.6. http://whc.unesco.org/documents/publi_wh_pap ers_06_en.pdf (Erişim Tarihi: 7 Mart 2014)

Gilbert CA (1985) Ebey's landing national historic reserve: Reading the Cultural Landscape. http://www.nps.gov/ebla/index.htm (Erişim Tarihi: 7 Mart 2014)

Gıda Tarım ve Hayvancılık Bakanlığı (1993) Rize ili arazi varlığı. Il Rapor No 53. Ankara: Gıda Tarım ve Hayvancılık Bakanlığı, Tarım Reformu Genel Müdürlüğü Yayınları.

Head L (2001) Cultural Landscape and Environmental Change. Oxford University Press A Hodder Arnold Publication, London.

Melnick RZ, Sponn D, Saxe EJ (1984) Cultural Landscape; Rural Historic Districts in the National Park System. National Park Service U.S. Dept. of the Interior, Washinghton D.C.

Özsüle Z (2005) Geleneksel Yerleşimlerin Korunması Açısından Kültürel Peyzaj 
Değerlendirmesi: Mudanya Örneği. İ.Ü. Fen Bilimleri Enstitüsü Doktora Tezi, İstanbul, 23s s.

Parks Canada (1994) An Approach to Cultural Landscapes. http://www.pc.gc.ca/eng/index.aspx (Erişim Tarihi: 7 Mart 2014)

Reis S, Bayrak T, Yalçın A, Sancar C, Erduran M, Atasoy M, Nişancı R, Ekercin S (2009) Rize iline (tr904) ait heyelan risk bölgeleri ve uygun yerleşim alanlarının coğrafi bilgi teknolojileri ile belirlenmesi. TÜBİTAK Proje No: $106 Y 018$.

TUIK (2009) Türkiye istatistik kurumu 2009 adrese dayalı nüfus sayımı Rize ili nüfusun sosyal ve ekonomik nitelikleri istatistikleri.

http://tuikapp.tuik.gov.tr/adnksdagitapp/adnks.z ul (Erişim Tarihi: 7 Mart 2014)

Turoğlu H (2000) Coğrafi bilgi sistemlerinin temel esasları. Acar Matbaacılık ve Yayıncılık Hizmetleri A.Ş. İstanbul.
Türk T (2003) Uzaktan algilama (UA) ve coğrafi bilgi sistemleri (CBS) kullanılarak tarım ve doğal alanlar üzerine kent baskısının belirlenmesi-Söke, Kuşadası ve Davutlar örneği. E.Ü. Fen Bilimleri Enstitüsü Doktora Tezi, İzmir, $172 \mathrm{~s}$.

Türkyılmaz B, Kurucu Y, Altınbaş Ü, Bolca M, Esetlili MT, Özen F, Gülgün B, Gencer G, Güney A, Hepcan Ş, Özden N, (2005) Doğal sitlerin belirlenmesi ve sinıflandırılmasinda coğrafi bilgi sisteminin kullanılabilirliği ve bir örnekleme alanında (Kaynaklar Beldesi-İzmir) Veri Tabanı Oluşturma Üzerinde Araştırmalar. TÜBITTAK Proje No: $102 Y 046$.

UNESCO (2009) Cultural landscape, http://whc.unesco.org/en/culturallandscape (Erişim Tarihi: 7 Mart 2014) 